\title{
Description of two new species of Nostoc from China based on the polyphasic approach
}

\author{
Fangfang CAI ${ }^{1,2}$, Gongliang YU ${ }^{2}$, Yuchen LIU ${ }^{1}$, Yuanquan $\mathrm{SUN}^{1} \&$ Renhui $\mathrm{Li}^{3 *}$ \\ ${ }^{1}$ Hubei Key Laboratory of Animal Nutrition and Feed Science, Hubei Collaborative Innovation Center for Animal \\ Nutrition and Feed Safety, Wuhan Polytechnic University, Wuhan 430023, China \\ ${ }^{2}$ Key Laboratory of Algal Biology, State Key Laboratory of Freshwater Ecology and Biotechnology of China, \\ Institute of Hydrobiology, Chinese Academy of Sciences, Wuhan 430072, China \\ ${ }^{3}$ School of Life and Environmental Sciences, Wenzhou University, Zhejiang 325035, China; *Corresponding \\ authore-mail:renhui.li@wzu.edu.cn
}

\begin{abstract}
The present study described two new Nostoc species, Nostoc favosum (CHAB5709, CHAB5713, and CHAB5714) and Nostoc mirabile (CHAB5756 and CHAB5784) based on the polyphasic approach combining morphological, genetic and ecological characteristics. Five investigated strains were found to possess morphological features of the Nostoc genus. Results showed that the 16S rRNA gene sequences of these five strains displayed $\geq 95 \%$, and $\leq 98 \%$ similarity to the genus Nostoc. The $16 \mathrm{~S}$ rRNA gene phylogenetic analysis inferred using bayesian inference, maximum-likelihood and neighbour-joining methods placed these five strains on two separate nodes away from other Nostoc species. The 16S-23S rRNA internal transcribed spacer (ITS) secondary structure of two new species showed a unique pattern of D1-D1', Box-B and V3 helix, which distinguished them from other Nostoc species. And the two species were further established by percent dissimilarity of ITS between another Nostoc species.
\end{abstract}

Key words: 16S rRNA gene, 16S-23S ITS, new species, morphology, polyphasic approach, taxonomy, Nostoc

\section{INTRODUCTION}

Cyanobacteria are a morphologically and ecologically diverse group of photoprokaryotes found around the globe (Graham et al. 2008). The traditionally classification of cyanobacteria was mainly based on morphological characteristics (KOMÁREK 2003; TATON et al. 2003, 2006; JoHANSEN \& CASAMATTA 2005; TURicChia et al. 2009; GENUÁRIO et al. 2013). But many cyanobacterial taxa are difficult to identify due to the lack of clear morphological characteristics and the vague or overly broad concept of modern genera. In recent decades, however, additional applications of molecular data using 16S rRNA gene sequences have greatly improved the classification and systematics of cyanobacteria (Robertson et al. 2001; KomÁreK 2006; Fiore et al. 2001; SiLva et al. 2014; BravaKos et al. 2016). This progress in taxonomic research resulted in the description of many new cyanobacterial genera, which are based on phylogenetic analyses. However, there still exist several unsolved problems in genera established after molecular sequencing (eg. identification of new taxa by ecologists, who do not use molecular analyses for determination of cyanobacteria in nature) (КOMÁREK 2020). In this situation, КомÁREK (2020) proposed that modern classification must be applied consistently the polyphasic approach with the phylogenetic classification as the basis, but it is necessary to combine and add all cytomorphological and ecological important data, and adequate use of nomenclature prescriptions.

Genus Nostoc, differed from other heterocytous cyanobacteria in that the trichomes with heterocytes and akinetes are embedded in colonial common mucilage. Despite being first reported in the 19th century with type species Nostoc commune VAUCHER ex BORNET et Flahault (Bornet \& Flahault 1888), its taxonomy remains complicated and problematic. To date, over 100 species of Nostoc have been described worldwide (GUIRY \& GUIRY 2021), most of these species have not yet been sequenced and have rarely been reported in the literature. Also this taxonomically complicated genus require nomenclatural revision (КомÁREK 2013). Many of described Nostoc species may belong to other genera, but is waiting for the taxonomical revision (such as Nostoc ellipsosporum V, Nostoc spongiaeforme Ind42, Nostoc verrucosum KU005, Nostoc insulare 
SAG 54.79, Nostoc carneum IAM M-35 and Nostoc piscinale CENA21 listed in NCBI database). In addition, Nostoc has repeatedly been proven to be genetically heterogeneous and polyphyletic (HrouzEK et al. 2005, 2013; Rajaniemi et al. 2005a; PAPAefthimiou et al. 2008; LUKEŠOVÁ et al. 2009; SILVA et al. 2014). With the advent of polyphasic approaches, some Nostoc-like genera have been separated from Nostoc in an attempt to make this genus less polyphyletic, including Mojavia (ŘEHÁKová et al. 2007), Desmonostoc (HrouzeK et al. 2013), Halotia (GENuÁrio et al. 2015), Aliinostoc (BAGCHI et al. 2017), Komarekiella (HENTSCHKE et al. 2017) and Desikacharya (SARAF et al. 2019). A subsequent recent study that isolated several strains from rocky mountain in China exhibit Nostoc-like appearance. The investigation showed molecular distinction and the observed cyanobacteria have been assigned with new names as Minunostoc, Compactonostoc, Purpureonostoc and Violetonostoc (CAI et al. 2019a, 2019b, 2020a, 2020b).

The study of terrestrial Nostoc-like cyanobacteria in China was limited till recent years, during a broader survey on Chinese terrestrial Nostoc-like cyanobacteria, we have found and described several new genera and species in the family Nostocaceae (CAI et al. 2018, 2019a, 2019b, 2020a, 2020b). In this study, we isolated morphologically distinct heterocytous cyanobacteria from seldomly sampled regions in China, such as Baishan city in Jilin province and Shennongjia Forestry District in Hubei province. A polyphasic approach was employed to intensively study five selected strains (CHAB5709, CHAB5713, and CHAB5714, CHAB5756 and CHAB5784). Morphological features were observed and studied at different stage of their life cycle. Morphologically, we concluded them as Nostoc, and molecular analysis confirmed its position in Nostoc sensu stricto. Moreover, phylogeny of 16S rRNA gene, the secondary structure through sequencing of internally transcribed spacer (ITS) between 16S rRNA and 23S rRNA of the ribosomal genes, and percent dissimilarity of ITS were also determined herein to estimate their exact taxonomic status. Overall, the analyses of morphology and molecular data revealed that these five strains did not match any described species of Nostoc. These results allowed us to describe two new Nostoc species, as Nostoc favosum and Nostoc mirabile.

\section{Materials AND Methods}

Sampling, isolation and culturing of strains. Samples used in this study were isolated from two different localities of China having different climatic and geographical conditions. The strains CHAB5709, CHAB5713 and CHAB5714 were isolated from the edge of a stream $\left(42^{\circ} 51.92^{\prime} \mathrm{N}, 127^{\circ} 78.94^{\prime} \mathrm{E}\right)$ in Baishan city, Jilin province, temperate climate in China. The strains CHAB 5756 and CHAB 5784 were collected from wet rocks in Shennongiia Forestry District $\left(31^{\circ} 44.62^{\prime} \mathrm{N}\right.$, $\left.110^{\circ} 30.92^{\prime} \mathrm{E}\right)$, located near the western border of Hubei province, a subtropical monsoon climate in China. Unialgal filaments from the cyanobacterial samples were isolated by lab-made Pasteur pipette under microscope (Olympus C31, Japan) and then cultured in screw capped tubes containing $6 \mathrm{ml}$ of BG11 medium. All isolates were subsequently cultivated at $25^{\circ} \mathrm{C}$ under a 12:12 h (light: dark) cycle with a photon flux density of $35 \mu \mathrm{mol} \cdot \mathrm{m}^{-2} \cdot \mathrm{s}^{-1}$ from white fluorescent lamps. The living culture were maintained in the Chinese Harmful Algae Biology (CHAB) culture collection of the Institute of Hydrobiology, China. And dry materials of strains were obtained by freezedrying at $-40^{\circ} \mathrm{C}$ and stored at the Freshwater Algal Herbarium (HBI), Institute of Hydrobiology, Chinese Academy of Science, Wuhan, China.

Morphological characterization. All live cultures were examined with a Nikon Eclipse 80i microscope (Nikon, Tokyo, Japan) using its differential interference contrast microscopy. Microphotographs were analyzed with Nikon software NIS-Elements 3.2D (Nikon, Tokyo, Japan). Morphometric characteristics included length and width of vegetative cells, heterocytes and akinetes, as well as the size of macrocolonies and microcolonies $(n>50)$ were described using the Nikon Eclipse $80 \mathrm{i}$ microscope equipped with a Nikon DS-Ri1 digital camera.

Molecular analysis. Total genomic DNA was isolated from liquid cultures of unialgal cyanobacterial strains using Clarke's (CLARKe 2009) method. The primers PA (EDWARDS et al. 1989) and B23S (Gkelis et al. 2005) were used to amplify the 16S rRNA gene. Primers 322 and 340 (ItEman et al. 2000) were used to obtain the $16 \mathrm{~S}-23 \mathrm{~S}$ ITS region. The PCR reaction contained $1 \mu \mathrm{l}$ of genomic DNA (100 ng ML $\left.{ }^{-1}\right), 0.5 \mu 1$ of each primer $\left(10 \mu \mathrm{mol}^{1} \mathrm{l}^{-1}\right), 8 \mu \mathrm{l}$ of sterile water and $10 \mu \mathrm{l}$ of $2 \times$ PCR mix with Taq polymerase (Cat TSE001, Beijing Tsingke BiotechCo., Ltd., Beijing, China), in a final volume of $20 \mu \mathrm{l}$. PCR was performed in an MJ Mini Personal Thermal Cycler (Bio-Rad, Hercules, California USA), and the PCR cycle had initial denaturation at $94{ }^{\circ} \mathrm{C}$ for $3 \mathrm{~min}$, followed by 34 cycles of $94^{\circ} \mathrm{C}$ for $30 \mathrm{~s}, 58^{\circ} \mathrm{C}$ for $30 \mathrm{~s}\left(30 \mathrm{~s}\right.$ at $55^{\circ} \mathrm{C}$ for ITS), $72{ }^{\circ} \mathrm{C}$ for $1 \mathrm{~min}$ (30s for ITS), and a final 5 min elongation step at $72{ }^{\circ} \mathrm{C}$. The PCR amplification products were purified using TSINGKE DNA Gel Extraction Kit (Cat GE0101-200, Beijing Tsingke Biotech Co., Ltd., Beijing, China) and then cloned into the pMDTM18-T vector (TaKaRa Bio Inc., Otsu, Japan) using the procedure of SAMBRoOK \& RUSSELL (2001). All sequencing was carried out by the ABI 3730 Automated Sequencer (PerkinElmer, Waltham, MA, USA). The 16S rRNA and 16S-23S ITS gene sequences of the cyanobacterial strains CHAB5709, 5713, 5714, 5756 and 5784, isolated in this study were deposited in the NCBI GenBank database under accession numbers: MW649141, MW649142, MW649809, MW649810, MW649811, MW652791, MW652792, MW652793, MW652794, and MW652795.

Phylogenetic analysis. 16S rRNA gene sequences obtained in this study and those representing main groups of heterocytous cyanobacteria retrieved from GenBank were used for phylogenetic analyses with in total 184 sequences. Sequences using MAFFT v7.312 (KATOH \& STANDLEY 2013) with auto-selected strategy FFT-NS-I (with default parameters) and visually checked in mega v.7.0.14 (Kumar et al. 2016). The phylogenetic trees were constructed using neighbor-joining (NJ), maximum likelihood (ML), and bayesian inference (BI). The $\mathrm{NJ}$ analysis using Kimura-2 model upon default parameters with 1000 bootstrap replicates were run via MEGA software X (Kumar et al. 2018). The BI was calculated with MrBayes 
v3.2.6 (RonQUIST et al. 2012) in the CIPRES Science Gateway V.3.3 (MilLER et al. 2015, http://www.phylo.org/), in the BI analyses, two runs of eight Markov chains were executed for 8 million generations, sampling every 100 generations, with $25 \%$ of the sampled trees discarded as burn-in (the average standard deviation of split frequencies is 0.003 ). In the ML analyses, a total of 10000 bootstrap replicates were conducted to evaluate the relative support for branches by performing ultrafast bootstrap on IQ-TREE web server (TRIFINOPOULOS et al. 2016). All phylogenetic tree consensus files were visualized in FigTree, v1.4.3 (RAmBaut 2016) with Chroococcidiopsis thermalis PCC7203 as the outgroup. Calculation of p-distance with pairwise deletion of gaps was done with MEGA software v.7.0.14 (KUMAR et al. 2016) and used to calculate sequence identity $[100 \times(1-\mathrm{p})]$ for $16 \mathrm{~S}$ rRNA data.

16S-23S secondary structure analysis. 16S-23S rRNA secondary structures of D1-D1', Box-B, and V3 helices were determined using "RNAstructure", ver. 5.6 (MATHEWS LAB 2013). The sequences containing both tRNA ${ }^{\text {Ile }}$ and tRNA ${ }^{\text {Ala }}$ were used for all ITS analyses (except for Nostoc neudorfense ARC8, which has no tRNA ${ }^{\text {Ile }}$ and tRNA ${ }^{\text {Ala }}$ ). Percent dissimilarity based on 16S-23S ITS was calculated based on p-distance.

\section{RESULTS}

Nostoc favosum F. Cai et R. Li sp. nov. (Fig. 1)

Description: Colonies spherical, start yellow green, and become to gray green. Filaments released by the colony rupture, covered with or without sheath, and the filaments densely entangled to form young colony. Within the colony, the filaments segmented into several small groups, and the small groups showing compartmentalization of mucilage, later to form small spherical colony. Consequently, the older colony consist of aggregations of microcolonies, just like a beehive. Eventually the older colony broken to release these small colonies. Sheath thick, colorless. Vegetative cells short barrel shaped to subspherical, or oblong, 2.7-3.1-3.8 $\mu \mathrm{m}$ long and 2.7-4.4-4.6 $\mu \mathrm{m}$ wide. Heterocytes subspherical, with a diameter of 2.8-4.3-4.9 $\mu \mathrm{m}$. Akinetes not observed during years of cultivation.

Reference strains: The living culture were deposited in Collection of Harmful Algae Biology (CHAB), Institute of Hydrobiology, Chinese Academy of Sciences, Wuhan, Hubei Province, China as strain CHAB5709, CHAB5713 and CHAB5714.

Type locality: Isolated from the edge of a stream in Jilin province, China $\left(42^{\circ} 51.92^{\prime} \mathrm{N}, 127^{\circ} 78.94^{\prime} \mathrm{E}\right)$.

Holotype here designated: Dry material of the strain CHAB5709 was stored at the Freshwater Algal Herbarium (HBI), Institute of Hydrobiology, Chinese Academy of Science, Wuhan, China, as specimen No. JLCN201401. Etymology: favosum = "favose", refers to typical morphological characteristics of this species.

Habitat: Free-living on edge of a stream in the soil.
Nostoc mirabile F. Cai et R. Li sp. nov. (Fig. 2)

Description: Thallus macroscopic in nature and in culture. In culture, forming macroscopic masses on test tube bottom in liquid media. On agar, macroscopic colonies, as aggregation of spherical colonies with distinct mucilage, which remain distinct throughout the whole life cycle. Macrocolonies dark green. Filaments with no sheath released from the colony, and later form distinct, colorless sheath, and terminal heterocyte outside of the sheath. Then the trichomes irregular, tightly entangled in the sheath, to form young long filamentous colony, the heterocytes appeared at the end of the colony. The sheath outside of the colony, shrank to separate the filamentous colony into smaller colonies. Later these smaller colonies connected by heterocyte, and eventually formed spherical colonies. Vegetative cells elliptic or spherical, 2.8-3.4-3.7 $\mu \mathrm{m}$ long and 3.0-3.5-3.9 $\mu \mathrm{m}$ wide. Heterocytes larger than vegetative cells, short barrel shaped that protrude from the population, subspherical within the colony. 3.3-3.9-4.2 $\mu \mathrm{m}$ long, 3.6-4.1-4.8 $\mu \mathrm{m}$ wide. Akinetes not observed during years of cultivation.

Reference strains: CHAB5756, CHAB5784, deposited in Collection of Harmful Algae Biology (CHAB), Institute of Hydrobiology, Chinese Academy of Sciences, Wuhan, Hubei Province, China.

Type locality: Isolated from wet rocks in Shennongjia Forestry District, Hubei province $\left(31^{\circ} 44.62^{\prime} \mathrm{N}, 110^{\circ} 30.92^{\prime} \mathrm{E}\right)$. Holotype here designated: Dry material of the strain CHAB5784 was stored at the Freshwater Algal Herbarium (HBI), Institute of Hydrobiology, Chinese Academy of Science, Wuhan, China, as specimen No. HBCN201402. Etymology: mirabile, referring to unique morphological characteristics of this species.

Habitat: Free-living on wet rocky substrates.

\section{Molecular and phylogenetic analysis}

The 16S rRNA gene sequences of the studied strains were obtained and evaluated with BLAST analyses in NCBI. The evolutionary distance matrix based on $16 \mathrm{~S}$ rRNA gene showed that three Nostoc favosum strains shared $99.3 \%-99.7 \%$ similarity with each other, but they shared $96 \%-98 \%$ similarities with other Nostoc species. Two Nostoc mirabile strains showed sequence similarity of $99.4 \%$ to each other, while they showed 95\%-97\% to other Nostoc species (Table 1). The $16 \mathrm{~S}$ rRNA phylogenetic trees of ML, NJ and BI were constructed with 184 nucleotide sequences including the studied strains, the nearly complete $16 \mathrm{~S}$ rRNA gene sequences after pairwise alignment was approximately 1166 bp. Bayesian tree showed that the studied Nostoc strains, together with other Nostoc species, formed a single cluster, and this unique cluster was supported by NJ, ML, BI approaches with high bootstrap values of $100 \%, 100 \%$, and 1.00, respectively (Fig. 3).

\section{S-23S ITS region}

The percent dissimilarity among aligned ITS sequences 


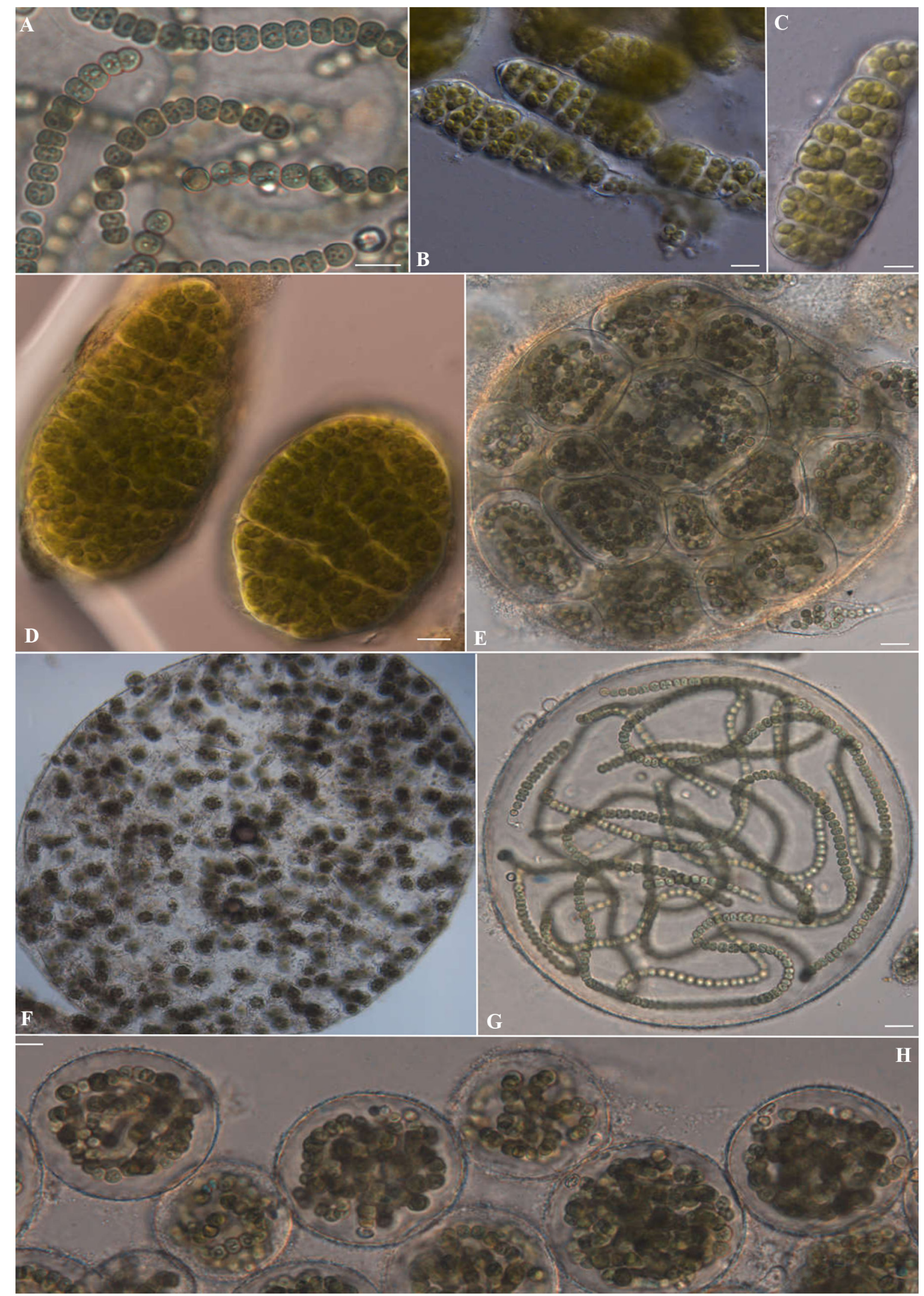

Fig. 1. Micrographs of Nostoc favosum under the light microscopy (LM): (A) free-living trichomes with or without heterocytes; (B-D) young colony with densely entangled filaments; (E-F) older colony with a honeycomb-like structure is composed of a number of smaller spherical microcolonies; $(\mathrm{G}-\mathrm{H})$ smaller spherical microcolonies released from the older colony. Scale bar $10 \mu \mathrm{m}$. 

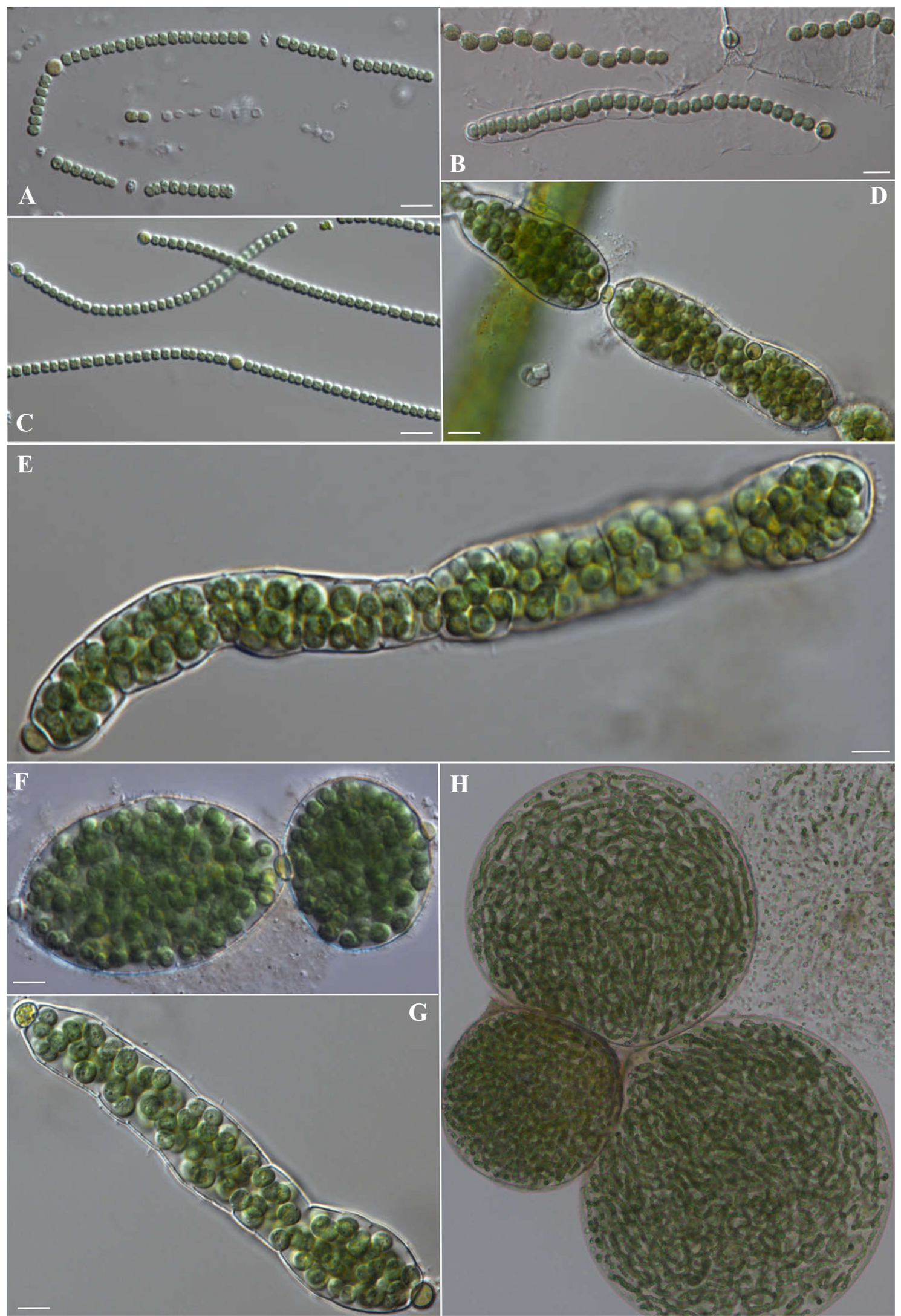

Fig. 2. Micrographs of Nostoc mirabile under the light microscopy (LM): (A-C) filaments with internal and terminal heterocytes; (E, G) filamentous young colony, showing heterocytes appeared at the end of the colony; (D, F) filamentous young colonies, connected by heterocytes; $(\mathrm{H})$ aggregation of spherical colonies with distinct mucilaginous. Scale bar $10 \mu \mathrm{m}$. 


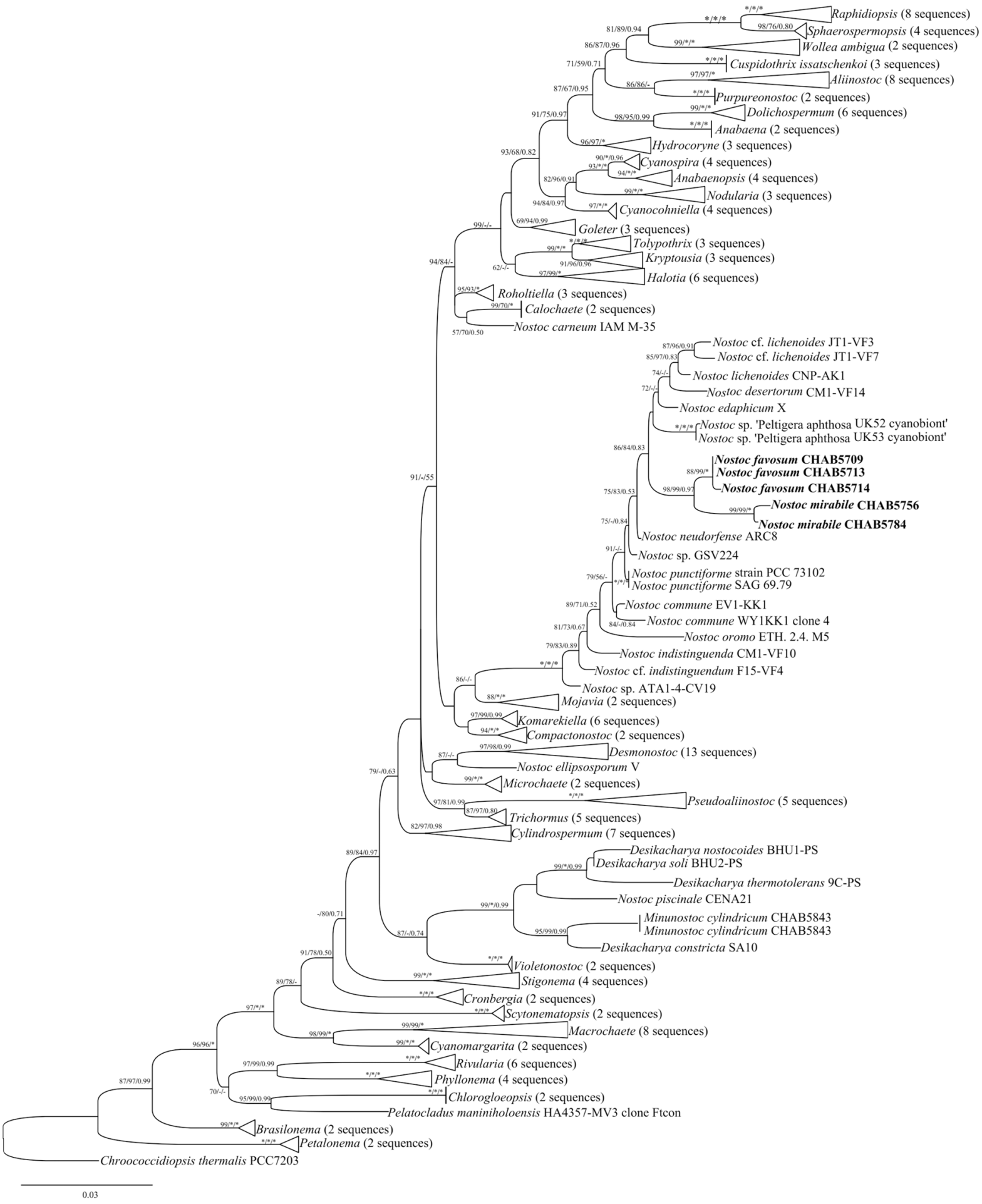

Fig. 3. Bayesian tree (BI) phylogenetic tree based on $16 \mathrm{~S}$ rDNA sequences (1166bp) of the studied strains and other cyanobacterial strains. Bootstrap values greater than $50 \%$ with NJ/ ML/Mrbayes methods are indicated on the tree, and the asterisks at the nodes mean 100 . The novel species are in bold font.

between our strains and the other Nostoc species for which ITS sequence with both tRNA genes was available, varied from $7.5 \%-16.6 \%$. Percent dissimilarity of Nostoc favosum to other species is in the range of $11.4 \%-14.6 \%$, and three Nostoc favosum strains shared $0.2 \%$ dissimilarity with each other. Percent dissimilarity of Nostoc mirabile to other species is in the range from
$11.2 \%$ to $16.6 \%$, and two Nostoc mirabile strains shared $0 \%$ dissimilarity with each other (Table 2 ).

The secondary structures of conserved ITS domains in Nostoc are highly similar (Figs 4-6), particularly in the D1-D1' helices which were structurally identical and had the similar patterns. Nostoc favosum and Nostoc mirabile showed different nucleotides in the 

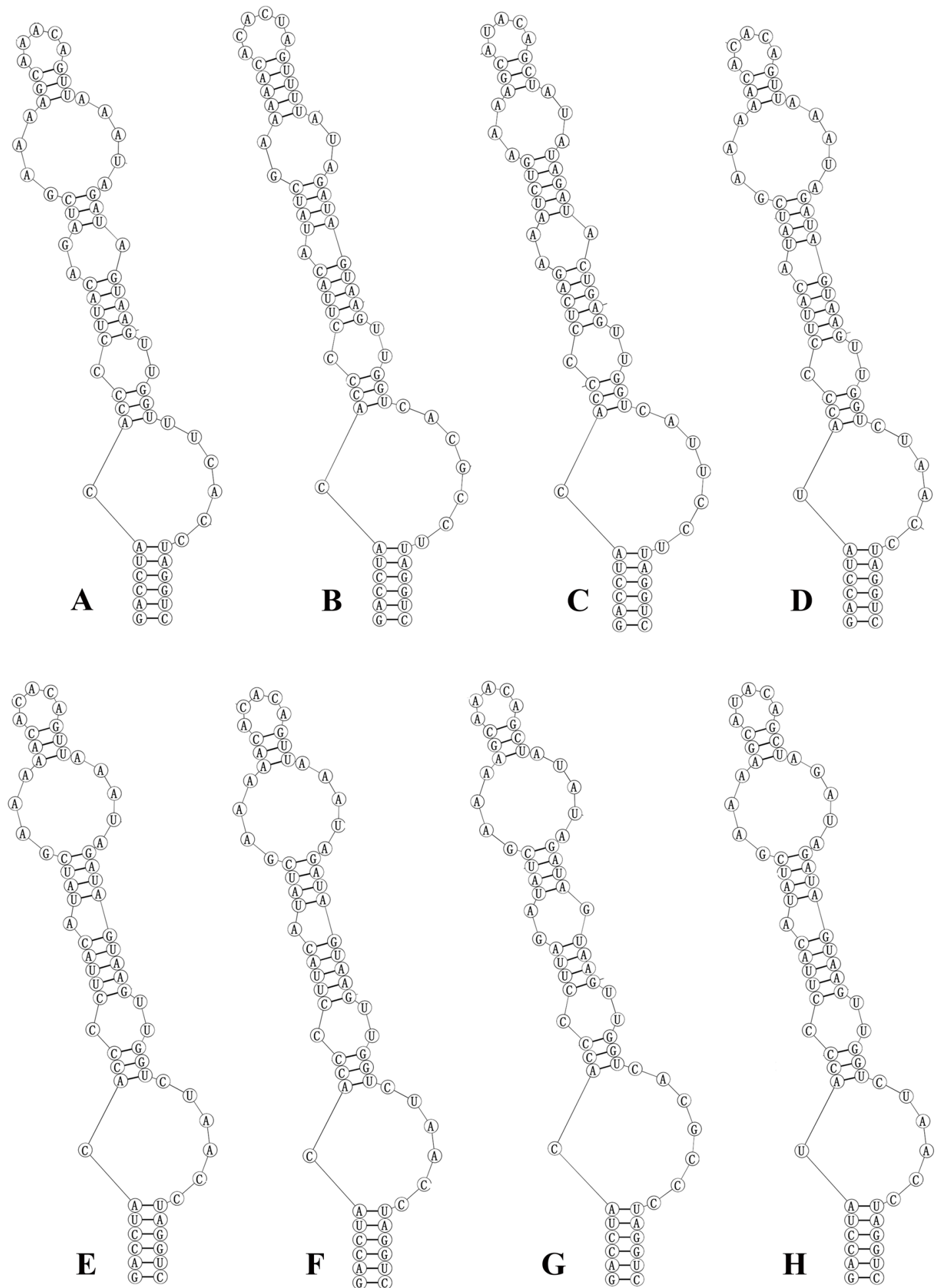

Fig. 4. Secondary structure of D1-D1' helix: (A) Nostoc mirabile CHAB5784, CHAB 5756; (B) Nostoc favosum CHAB5709, CHAB5713, CHAB5714; (C) Nostoc commune WY1-KK1; (D) Nostoc punctiforme PCC73102; (E) Nostoc desertorum CM1-VF14; (F) Nostoc indistinguendum CM1-VF10; (G) Nostoc lichenoides CNP-AK1; (H) Nostoc oromo ETH2.4.M5.

D1-D1' helix in comparison with other Nostoc species (Fig. 4A and 4B).

The Box-B helices of Nostoc were all very similar at the basal part of the helix, but the sequences and structure at the end are different, the eight Nostoc species were divided into the eight types (Fig. 5). The base stem of the Box-B helix of Nostoc mirabile (Fig.
5A) consisted of 5 bp helix, followed by a $3: 3$ base bilateral bulge, and then further followed by a unpaired nucleotide (A) on 3 ' side, the terminal loop contained 5 bp bases (GAUGA). The base stem of Nostoc favosum (Fig. 5B) consisted of $5 \mathrm{bp}$ helix, and then followed by a $3: 3$ base bilateral bulge, the terminal loop contained 6 bp bases (UUAAUU). 


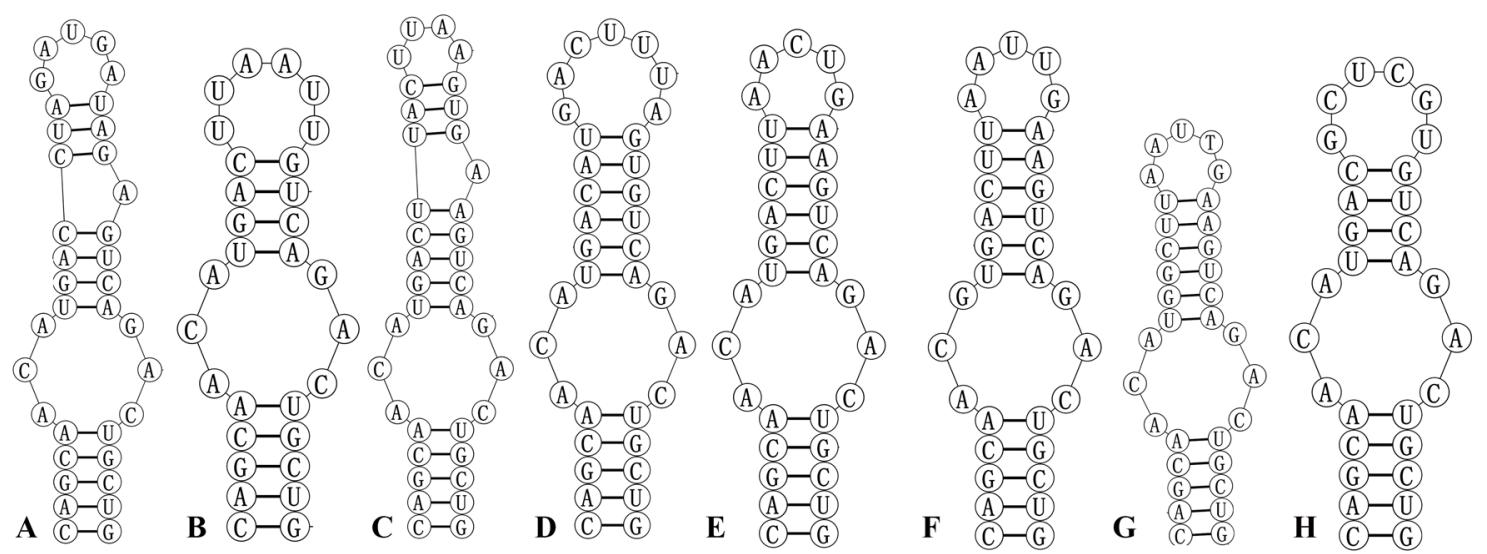

Fig. 5. Secondary structure of Box-B helix: (A) Nostoc mirabile CHAB5784, CHAB 5756; (B) Nostoc favosum CHAB5709, CHAB5713, CHAB5714; (C) Nostoc commune WY1-KK1; (D) Nostoc punctiforme PCC73102; (E) Nostoc desertorum CM1-VF14; (F) Nostoc indistinguendum CM1-VF10; (G) Nostoc lichenoides CNP-AK1; (H) Nostoc oromo ETH2.4.M5.

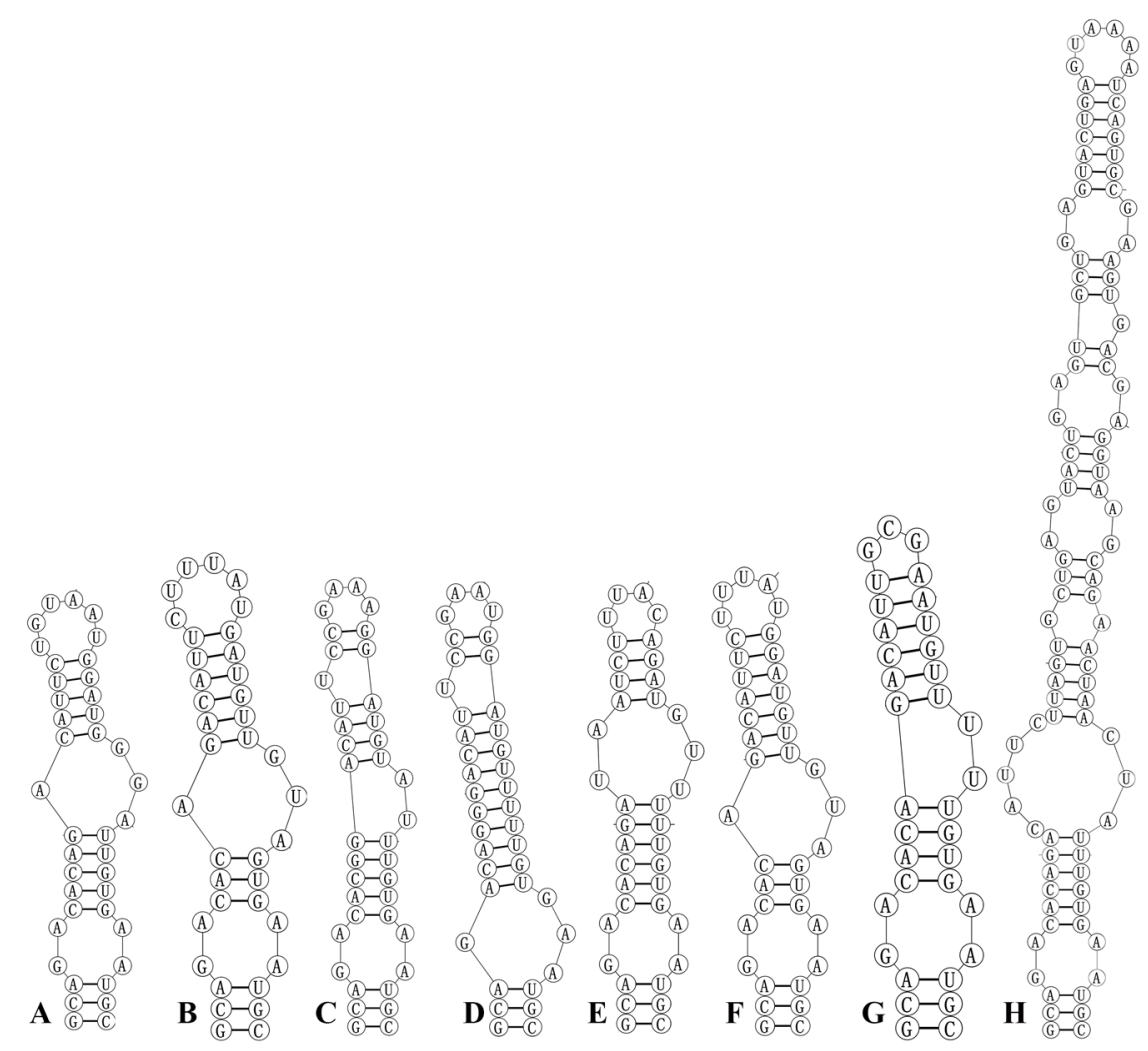

Fig. 6. Secondary structure of V3 helix: (A) Nostoc mirabile CHAB5784, CHAB 5756; (B) Nostoc favosum CHAB5709, CHAB5713, CHAB5714; (C) Nostoc commune WY1-KK1; (D) Nostoc punctiforme PCC73102; (E) Nostoc desertorum CM1-VF14; (F) Nostoc indistinguendum CM1VF10; (G) Nostoc oromo ETH2.4.M5; (H) Nostoc lichenoides CNP-AK1.

The V3 helices were similar only in the base part and varied in structure and length (Fig. 6). The base stem of Nostoc mirabile (Fig. 6A) consisted of 3 bp helix, followed by a $2: 2$ base bilateral bulge, and then further followed by a $1: 3$ base bilateral bulge, the terminal loop contained 6 bp bases (UGUAAU). The base of the stem of Nostoc favosum (Fig. 6B) consisted of 3 bp helix, and then followed by two bilateral bulges, the terminal loop contained a 6 bp nucleosides (CUUUAU).

\section{Discussion}

Due to the morphological plasticity, complex life cycle, and huge diversity, the taxonomy of genus Nostoc becomes problematic (MollenHAUER et al. 1999; KоMÁREK et al. 2014; SINGH et al. 2016). Molecular data showed up that the genetic diversity of the genus exceeded its morphological diversity, which clearly supported its polyphyletic status (RAJANIEMI et al. 2005a, 2005b; ŘEHÁKová et al. 2007; HrouzeK et al. 2013; GeNuÁrio 
et al. 2015; BAGCHI et al. 2017; HeNTSCHKE et al. 2017). Recent efforts have been made to reevaluate the genus by recognizing Nostoc sensu stricto, a clade that includes the type species, Nostoc commune, and excludes species that fall outside this clade that bear the name Nostoc, but cannot be put in that genus if monophyly must be achieved at the genus level (ŘEHÁKoví et al. 2007; HrouzeK et al. 2013; GenUÁRIO et al. 2015; BAGCHI et al. 2017; HentschKe et al. 2017; SARAF et al. 2019; CAI et al. 2019a, 2019b, 2020a, 2020b).

Taxonomical studies have found that molecular evidences, morphological, biogeographical, and ecological data are often consistent, and their combination can better distinguish species with similar morphology. This is the essence of the polyphasic approach, which has been followed when making decisions at the species level (KoMÁreK 2018; MAI et al. 2018). In this study, the species Nostoc favosum and Nostoc mirabile were characterized on the basis of the polyphasic approach. The phylogenetic analyses in this study, combined with the cut off values for the genus and species delimitation, clearly indicated that investigated strains are member of the genus Nostoc. In the 16S rRNA gene phylogenetic tree, Nostoc favosum and Nostoc mirabile clustered within the Nostoc branch at a unique node. This indicated that species Nostoc favosum and Nostoc mirabile are new members of the genus Nostoc. The original identity cut-off value recommended for separation of bacterial species was 97.5\% (STACKEBRANDT \& Goebel 1994). However, on the basis of extensive comparison of more bacterial strains, STACKEBRANDT \& EBERs (2006) recommended 98.7-99.0\% of $16 \mathrm{~S}$ rRNA gene sequence similarity as the species threshold. Other research proposed that $98.65 \%$ of $16 \mathrm{~S}$ rRNA gene sequence similarity could be used as a threshold to distinguish two species based on twofold cross-validation statistical test (KIM et al. 2014). The highest 16 S rRNA gene sequence similarity between the Nostoc favosum strains detected in this study and other Nostoc strains (Nostoc cf. lichenoides JT1-VF3) is 98\%. The highest 16S rRNA gene sequence similarity of Nostoc mirabile strains with other Nostoc strains is $97 \%$, which provided the molecular evidence to support the recognition of the two species we have named.

Up to now, four species, Desikacharya nostocoides (the type species of Desikacharya), Desikacharya soli, Desikacharya thermotolerans and Desikacharya constricta have been reported under the genus Desikacharya, which are considered certain features such as constrictions along with prominent coiling (KABIRNATAJ et al. 2020). KABIRNATAJ et al. (2020) discussed that Minunostoc cylindricum should be a member of the genus Desikacharya, in contrast, the Desikacharya species within the lineage, were differentiated into two distinct clades

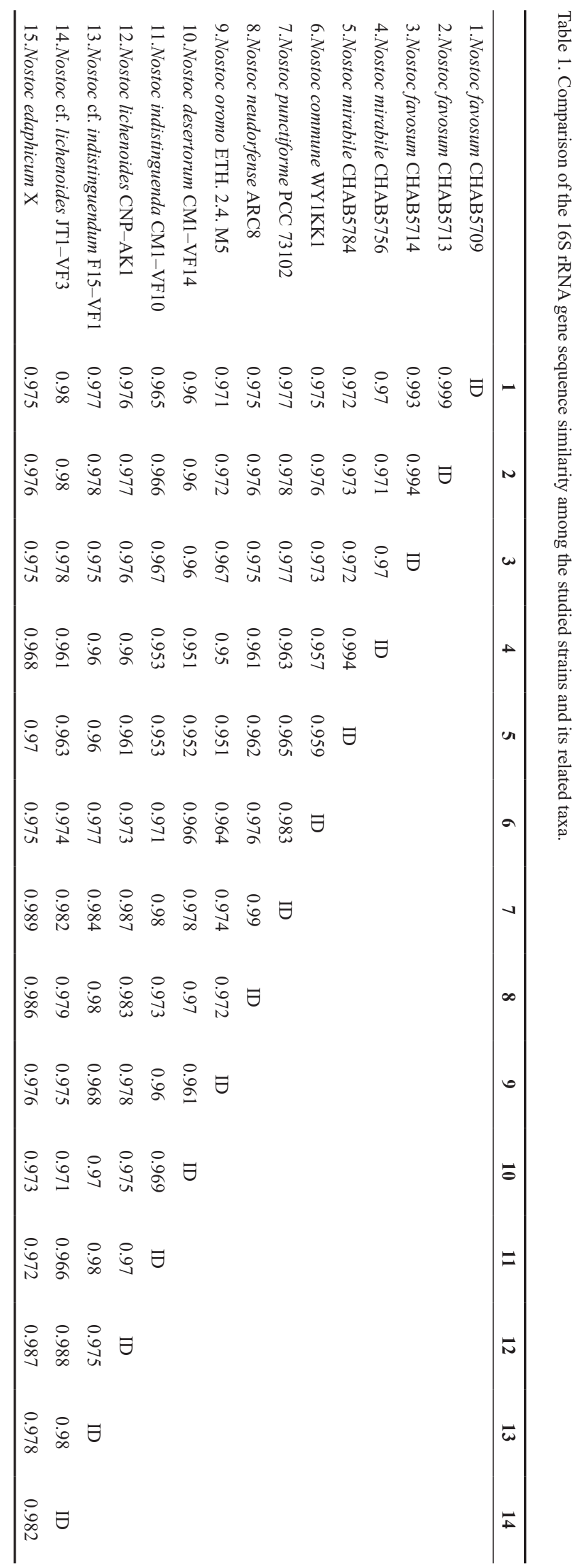


with high genetic divergences (less than $95 \%$ similarity of 16S rRNA gene), and Desikacharya has been shown to be polyphyletic in our analyses. The $16 \mathrm{~S}$ rRNA gene sequence of Desikacharya constricta had less than 95\% similarities to the type species Desikacharya nostocoides and Desikacharya soli, however, it had $96.9 \%$ similarity to Minunostoc cylindricum. The phylogenetic tree also showed that the sequence of Desikacharya constricta clustered within the Minunostoc clade. In addition, the 16S rRNA gene sequence similarities between Minunostoc cylindricum and other Desikacharya strains (except for Desikacharya constricta) were shown as less than 95\%, below the bacterial genus cut-off (Table S1). Thus, we conclude that Minunostoc cylindricum should not belong to the genus Desikacharya (below 95\% sequences similarities is a strong evidence for separation of genera), and the taxonomic status of Desikacharya constricta should be separated from the Desikacharya genus, and belonged to the Minunostoc genus.

The 16S-23S ITS secondary structure analysis has been demonstrated to be effective tool to differentiate cyanobacteria species (ITEMAN et al. 2000; ŘEHÁKOvá et al. 2007; JOHANSEN et al. 2011; BOHUNICKÁ et al. 2015; BERRENDERO-GóMEZ et al. 2016; MAREŠ 2018). In this study, the secondary structures of D1-D1', Box-B and V3 helices were also analyzed, which enabled our strains to be distinguished from other Nostoc species. It is shown here that D1-D1', Box-B and V3 helices of Nostoc favosum and Nostoc mirabile strains were quite different from other selected Nostoc species. In addition, the percent dissimilarity within the $16 \mathrm{~S}-23 \mathrm{~S}$ ITS region is increasingly useful for cyanobacterial species delimitation. Percent dissimilarity within the same species has always been less than $4.0 \%$, with an average value below $2.0 \%$, percent dissimilarity between species is typically over $7.0 \%$ (ERWIN \& THACKER 2008; OSORIO-SANTOS et al. 2014; PIETRASIAK et al. 2014; BoHUNICKÁ et al. 2015; MAI et al. 2018; Mesfin et al. 2020). Nostoc favosum is distinct from the other Nostoc species based on percent dissimilarity of the ITS region, which is $>11.4 \%$, and Nostoc mirabile is $>11.2 \%$ (Table 2 ). And dissimilarity in the ITS regions between these two new taxa is well above the $4 \%$ level. This fits well within the criteria for species differentiation based on percent dissimilarity of $>4.0 \%$. So, in this study, the percent dissimilarity in the ITS regions strongly supported their separation into two new Nostoc species.

Morphologically, the Nostoc mirabile strains closely resembles Nostoc punctiforme (HARIOT 1891, p. 31), having filamentous colony stage, heterocytes appeared at the end of the colony, and densely entangled filaments in colony. Nostoc mirabile create macroscopic colonies observable without microscopy, whereas Nostoc punctiforme is only microscopic in nature. In addition, the phylogenetic analysis of the $16 \mathrm{~S}$ rDNA, 16S rRNA gene similarity and the 16S-23S ITS, show that Nostoc mirabile and Nostoc punctiforme are genetically not closely related. The morphologically closet Nostoc species to

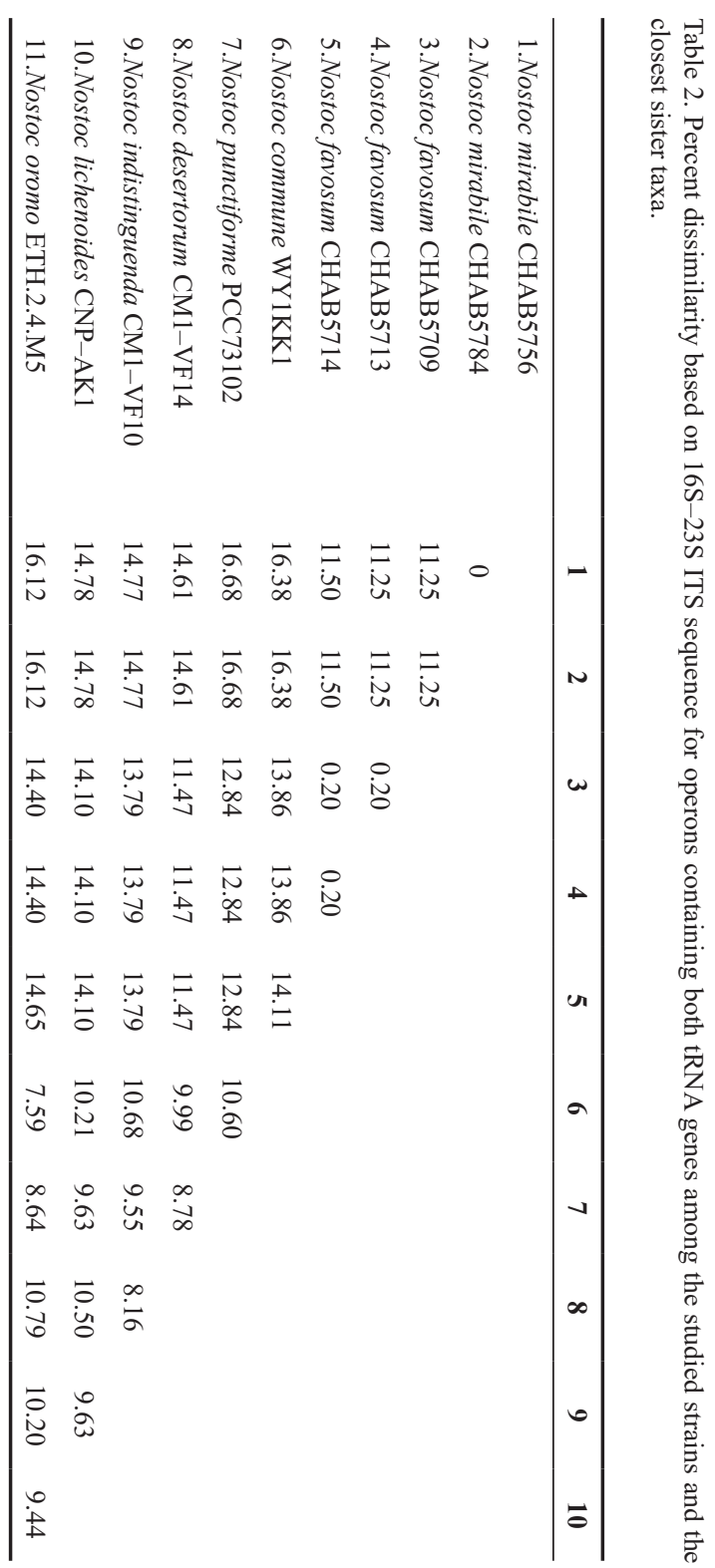

Nostoc favosum in the literature is Nostoc desertorum ŘEHÁKová et JoHANSEN (2007, p. 488, Figs 2, 27-33), described from sandy desert soil in California. Nostoc desertorum shares the characteristic of compartmentalization of colonial mucilage in older colony. Nostoc favosum differs in that the filaments segmented into several small groups in young colony, later many small groups grow into spherical colony, surrounded by large spherical sheath. Nostoc desertorum can form fairly flat masses in culture, a feature never seen in Nostoc favosum. Ecologically, Nostoc favosum strains were described from the edge of a stream, humid climate very different from the sandy desert soil habitat in which Nostoc desertorum was found.

In summary, two new species of Nostoc are separated based on a combination of the 16S rRNA gene-based phylogeny, 16S rRNA gene threshold of $98.65 \%$, the ITS secondary structures, $16 \mathrm{~S}-23 \mathrm{~S}$ ITS percent similarity, as well as morphological characteristics 
and ecological parameters. In China, the investigation and researches on Nostoc-like cyanobacteria from all kinds of environmental conditions have been largely performed, and several new genera and species have been found and published in the family Nostocaceae. The investigation of less studied regions and habitats in China could reveal the diversity of family Nostocaceae and bring new inside into the diversity of cyanobacteria on the world.

\section{ACKNOWLEDGMENTS}

This research was supported by the National Natural Science Foundation of China (32000166) and Science and Technology Research Program of Hubei Provincial Department of Education (Q20201609).

\section{REFERENCES}

Bagchi, S.N.; Dubey, N. \& Singh, P. (2017): Phylogenetically distant clade of Nostoc-like taxa with the description of Aliinostoc gen. nov. and Aliinostoc morphoplasticum sp. nov. - International Journal of Systematic and Evolutionary Microbiology 67: 3329-3338.

BerRendero-GómEZ, E.; JoHANSEN, J.R.; KAŠTOVSKÝ, J.; BoHUNICKÁ, M. \& ČAPKOvÁ, K. (2016): Macrochaete gen. nov. (Nostocales, Cyanobacteria), a taxon morphologically and molecularly distinct from Calothrix. - Journal of Phycology 52: 638-55.

Bravakos, P.; Kotoulas, G.; Skaraki, K.; Pantazidou, A. \& ECONOMOU-AMiLli, A. (2016): A polyphasic taxonomic approach in isolated strains of Cyanobacteria from thermal springs of Greece. - Molecular Phylogenetics and Evolution 98: 147-160.

Bornet, E. \& Flahault, C. (1888): Revision des Nostocacées hétérocystées contenues dans les principaux herbiers de France (quatrième et dernier fragment). - Ann des Sci Nat Bot 7: 177-262.

BohunickÁ, M.; PietrasiaK, N.; Johansen, J.R.; BerRenderoGómez, E.; Hauer, T.; GaYsina, L.A. \& LukeŠová, A. (2015): Roholtiella, gen. nov. (Nostocales, Cyanobacteria) - a tapering and branching cyanobacteria of the family Nostocaceae. - Phytotaxa 197: 84-103.

CaI, F.; Yang, Y.; Wen, Q. \& Li, R. (2018): Desmonostoc danxiaense sp. nov. (Nostocales, Cyanobacteria) from Danxia mountain in China based on polyphasic approach. - Phytotaxa 367: 233-244.

Cai, F.; Li, X.; Geng, R.; Peng, X. \& Li, R. (2019a): Phylogenetically distant clade of Nostoc-like taxa with the description of Minunostoc gen. nov. and Minunostoc cylindricum sp. nov. - Fottea 19: 13-24.

CAI, F.; LI, X.; YANG, Y.; JiA, N.; HUO, D. \& LI, R. (2019b): Compactonostoc shennongjiaensis gen. \& sp. nov. (Nostocales, Cyanobacteria) from a wet rocky wall in China. - Phycologia 58: 200-210.

CAI, F. \& LI, R. (2020a): Purpureonostoc, a new name for a recently described genus of Nostoc-like cyanobacteria. - Fottea 20: 111

CAI, F.; Peng, X. \& LI, R. (2020b): Violetonostoc minutum gen. et sp. nov. (Nostocales, Cyanobacteria) from a rocky substrate in China. - Algae 35: 1-15.

Clarke, J.D. (2009): Cetyltrimethyl ammonium bromide (CTAB) DNA miniprep for plant DNA isolation. - Cold Spring Harbor Protocols pdb-prot5177.

Edwards, U.; Rogall, T.; BlÖcker, H.; EMde, M. \& Böttger,
E.C. (1989): Isolation and direct complete nucleotide determination of entire genes. Characterization of a gene coding for $16 \mathrm{~S}$ ribosomal RNA. - Nucleic Acids Research 17: 7843-7853.

ERWIN, P.M. \& ThackeR, R.W. (2008): Cryptic diversity of the symbiotic cyanobacterium Synechococcus spongiarum among sponge host. - Molecular Ecology 17: 2937-2947.

Fiore, M.F.; Sant'anna, C.L.; Azevedo, M.; KomáreK, J.; KAŠTovsKÝ, J.; SuleK, J. \& Lorenzi, A.S. (2007): The cyanobacterial genus Brasilonema, gen. nov., a molecular and phenotypic evaluation. - Journal of Phycology 43: 789-798.

Genuário, D.B.; CorrêA, D.M.; KomáreK, J. \& Fiore, M.F. (2013): Characterization of freshwater benthic biofilmforming Hydrocoryne (Cyanobacteria) isolates from Antarctica. - Journal of Phycology 49: 1142-1153.

Genuário, D.B.; VAz, M.G.M.V.; HentschKe, G.S.; SANT'ANNA, C.L. \& Fiore, M.F. (2015): Halotia gen. nov., a phylogenetically and physiologically coherent cyanobacterial genus isolated from marine coastal environments. International Journal of Systematic and Evolutionary Microbiology 65: 663-675.

Gkelis, S.; Rajaniemi, P.; VardaKa, E.; MoustaKa-Gouni, M.; Lanaras, T. \& Sivonen, K. (2005): Limnothrix redekei (Van Goor) Meffert (Cyanobacteria) strains from Lake Kastoria, Greece form a separate phylogenetic group. - Microbial Ecology 49: 176-182.

Graham, J.E.; Wilcox, L.W. \& Graham, L.E. (2008): Algae, 2nd Ed. -720 pp., Benjamin Cummings, San Francisco, CA, USA.

GuIRY, M.D. \& GuIRY, G.M. (2021): AlgaeBase. - World-wide electronic publication, National University of Ireland, Galway. http://www.algaebase.org; searched on 19 February 2021.

Hentschke, G.S.; Johansen, J.R.; Pietrasiak, N.; Rigonato, J.; FioRe, M.F. \& SANT'ANNA, C.L. (2017): Komarekiella atlantica gen. et sp. nov. (Nostocaceae, Cyanobacteria): a new subaerial taxon from the Atlantic Rainforest and Kauai, Hawaii. - Fottea Olomouc 17: 178-190.

HrouzeK, P.; ventura, S.; Lukešová, A.; Mugnai, M.A.; TURICCHIA, S. \& KOMÁREK, J. (2005): Diversity of soil Nostoc strains: phylogenetic and phenotypic variability. - Algological Studies 117: 251-264.

HrouzeK, P.; LuKeŠová, A.; Mareš, J. \& Ventura, S. (2013): Description of the cyanobacterial genus Desmonostoc gen. nov. including D. muscorum comb. nov. as a distinct, phylogenetically coherent taxon related to the genus Nostoc. - Fottea 13: 201-213.

ItEMAN, I.; RiPPKA, R.; TANDEAU DE MARSAC, N. \& HeRdMAN, M. (2000): Comparison of conserved structural and regulatory domains within divergent $16 \mathrm{~S}$ rRNA-23S rRNA spacer sequences of cyanobacteria. - Microbiology 146: $1275-1286$.

Johansen, J.R. \& CASAMATtA, D.A. (2005): Recognizing cyanobacterial diversity through adoption of a new species paradigm. - Algological Studies 117: 71-93.

Johansen, J.R.; KováČiK, L.; CasamatTa, D.A.; FuČIKová, K. \& KAŠTOVSKÝ, J. (2011): Utility of 16S-23S ITS sequence and secondary structure for recognition of intrageneric and intergeneric limits within cyanobacterial taxa: Leptolyngbya corticola sp. nov. (Pseudanabaenaceae, Cyanobacteria). - Nova Hedwigia 92: 283-302.

KatoH, K. \& Standley, D.M. (2013): MAFFT multiple sequence alignment software version 7: improvements 
in performance and usability. - Molecular biology and evolution 30: 772-780.

Kabirnataj, S.; Nematzadeh, G.A.; Talebi, A.F.; Saraf, A.; Suradkar, A.; Tabatabaei, M. \& Singh, P. (2020): Description of novel species of Aliinostoc, Desikacharya and Desmonostoc using a polyphasic approach. - International Journal of Systematic and Evolutionary Microbiology 70: 3413-3426. DOI: https://doi.org/10.1099/ijsem.0.004188.

KIM, M.; OH, H.S.; PARK, S.C. \& ChUn, J. (2014): Towards a taxonomic coherence between average nucleotide identity and $16 \mathrm{~S}$ rRNA gene sequence similarity for species demarcation of prokaryotes. - International Journal of Systematic and Evolutionary Microbiology 64: $346-351$

KomÁreK, J. (2003): Problem of the taxonomic category "species" in cyanobacteria. - Algological Studies 109: 281-297.

KomÁReK, J. (2006): Cyanobacterial taxonomy: current problems and prospects for the integration of traditional and molecular approaches. - Algae 21: 349-375.

KomÁReK, J. (2013): Cyanoprokaryota. 3. Heterocytous genera. - In: BÜDEL, B.; GÄRTNER, G.; KRIENITZ, L. \& SCHAGERL, M. (eds): Süswasserflora von Mitteleuropa/ freshwater flora of Central Europe, Vol. 19/3. - 1131 pp., Springer, Heidelberg.

KomáreK, J.; KaštovskÝ, J.; Mareš, J. \& Johansen, J.R. (2014): Taxonomic classification of cyanoprokaryotes (cyanobacterial genera) 2014, using a polyphasic approach. - Preslia 86: 295-335.

KomÁreK, J. (2018): Several problems of the polyphasic approach in the modern cyanobacterial system. Hydrobiologia 811: 7-17.

KomÁrek, J. (2020): Quo vadis, taxonomy of cyanobacteria (2019). - Fottea 20: 104-110.

Kumar, S.; Stecher, G. \& Tamura, K. (2016): MEGA7: Molecular Evolutionary Genetics Analysis version 7.0 for bigger datasets. - Molecular Biology and Evolution 33: 1870-1874.

Kumar, S.; Stecher, G.; Li, M.; Knyaz, C. \& Tamura, K. (2018): MEGA X: Molecular Evolutionary Genetics Analysis across computing platforms. - Molecular Biology and Evolution 35: 1547-1549.

Lukešoví, A.; Johansen, J.R.; Martin, M.P. \& CASAMatTA, D.A. (2009): Aulosira bohemensis sp. nov.: Further phylogenetic uncertainty at the base of the Nostocales (Cyanobacteria). - Phycologia 48: 118-129.

Mathews Lab. (2013): RNAstructure, version 5.6. Available from: http://rna.urmc.rochester.edu/RNAstructure.html.

MAREŠ, J. (2018): Multilocus and SSU rRNA gene phylogenetic analyses of available cyanobacterial genomes, and their relation to the current taxonomic system. - Hydrobiologia 811: 19-34.

Mai, T.; Johansen, J.R.; Pietrasiak, N.; Bohunická, M. \& Martin, M.P. (2018): Revision of the Synechococcales (cyanobacteria) through recognition of four families including Oculatellaceae fam. nov. and Trichocoleaceae fam. nov. and six new genera containing 14 species. Phytotaxa 365: 001-059.

Mesfin, M.; Johansen, J.R.; Pietrasiak, N. \& Baldarelli, L.M. (2020): Nostoc oromo sp. nov. (nostocales, cyanophyceae) from ethiopia: a new species based on morphological and molecular evidence. - Phytotaxa 433: 081-093.

Miller, M.; Schwartz, T.; Pickett, B.; He, S.; Klem, E.; Scheuermann, R.H.; Passarotti, M.; Kaufman, S. \&
O'LeAry, M.A. (2015): A RESTful API for Access to Phylogenetic Tools via the CIPRES Science Gateway. - Evolutionary Bioinformatics 11: 43-48.

Mollenhauer, D.; Bengtsson, R. \& Lindstrøm, E-A. (1999): Macroscopic cyanobacteria of the genus Nostoc: a neglected and endangered constituent of European inland aquatic biodiversity. - European Journal of Phycology 34: 349-360.

Osorio-Santos, K.; Pietrasiak, N.; Bohunická, M.; Miscoe, L.H.; KováČIK, L.; MARTIN, M.P. \& JOHANSEN, J.R. (2014): Seven new species of Oculatella (Pseudanabaenales, Cyanobacteria): taxonomically recognizing cryptic diversification. - European Journal of Phycology 49: 450-470.

Papaefthimiou, D.; HrouzeK, P.; Mugnai, M.A.; Lukesova, A.; Turicchia, S.; Rasmussen, U. \& Ventura, S. (2008): Differential patterns of evolution and distribution of the symbiotic behaviour in nostocacean cyanobacteria. International Journal of Systematic and Evolutionary Microbiology 58: 553-564.

Pietrasiak, N.; Mühlisteinová, R.; Siegesmund, M.A. \& JohANSEN, J.R. (2014): Phylogenetic placement of Symplocastrum (Phormidiaceae, Cyanophyceae) with a new combination $S$. californicum and two new species: S. fletchnerae and S. torsivum. - Phycologia 53: 529-541.

Rajaniemi, P.; HrouzeK, P.; Kaštovská, K.; Willame, R.; Rantala, A.; Hoffmann, L.; KomáreK, J. \& Sivonen, K. (2005a): Phylogenetic and morphological evaluation of the genera Anabaena, Aphanizomenon, Trichormus and Nostoc (Nostocales, Cyanobacteria). - International Journal of Systematic and Evolutionary Microbiology 55: 11-26.

Rajaniemi, P.; Komárek, J.; Willame, R.; Hrouzek, P.; KAŠTovSKÁ, K.; HofFMANN, L. \& Sivonen, K. (2005b): Taxonomic consequences from the combined molecular and phenotype evaluation of selected Anabaena and Aphanizomenon strains. - Algological Studies 117: 371-391.

Rambaut, A. (2016): FigTree v1.4.3 2006-2016. Tree Figure Drawing Tool. Online publication. - Institute of Evolutionary Biology, University of Edinburgh. https:// vcru.wisc.edu/simonlab/bioinformatics/ programs/ fgtree/README.txt.

Řeháková, K.; Johansen, J.R.; Casamatta, D.A.; Xuesong, L. \& VINCENT, J. (2007): Morphological and molecular characterization of selected desert soil cyanobacteria: three species new to science including Mojavia pulchra gen. et sp. nov. - Phycologia 46: 481-502.

Robertson, B.R.; TezuKa, N. \& Watanabe, M.M. (2001): Phylogenetic analyses of Synechococcus strains (Cyanobacteria) using sequences of $16 \mathrm{~S}$ rDNA and part of the phycocyanin operon reveal multiple evolutionary lines and reflect phycobilin content. - International Journal of Systematic and Evolutionary Microbiology 51: 861-871.

Ronquist, F.; Teslenko, M.; VAn der Mark, P.; Ayres, D.L.; Darling, A.; HÖhna, S.; Larget, B. LiU, L.; Suchard, M.A. \& HueLSENBECK, J.P. (2012): MrBayes 3.2: Efficient bayesian phylogenetic inference and model choice across a large model space. - Systematic Biology 61: 539-542.

SARAF, A.G.; DAwDA, H.G. \& Singh, P. (2019): Validation of the genus Desikacharya gen. nov. (Nostocaceae, Cyanobacteria) and three included species. - Notulae 
Algarum 107: 1-3.

SAmbrook, J. \& Russell, D.W. (2001): Molecular cloning: a laboratory manual. - 2344 pp., CSHL Press, Cold Spring Harbor, New York, USA.

Silva, C.S.P.; Genuário, D.B.; VAZ, M.G.M.V. \& Fiore, M.F. (2014): Phylogeny of culturable cyanobacteria from Brazilian mangroves. - Systematic and Applied Microbiology 37: 100-112.

Singh, P.; Shaikh, Z.M.; Gaysina, L.A.; Suradkar, A. \& Samanta, U. (2016): New species of Nostoc (cyanobacteria) isolated from Pune, India, using morphological, ecological and molecular attributes. - Plant Systematic and Evolution 302: 1381-1394.

Stackebrandt, E. \& Goebel, B.M. (1994): Taxonomic note: a place for DNA-DNA reassociation and 16S rRNA sequence analysis in the present species definition in bacteriology. - International Journal of Systematic Bacteriology 44: 846-849.

StackebrandT, E. \& Ebers, J. (2006): Taxonomic parameters revisited: tarnished gold standards. - Microbiol Today 33: $152-155$

Taton, A.; Grubisic, S.; Brambilla, E.; De Wit, R. \& Wilmotte, A. (2003): Cyanobacterial diversity in natural and artificial microbial mats of Lake Fryxell (McMurdo Dry Valleys, Antarctica): a morphological and molecular approach. - Applied and Environmental Microbiology 69: 5157-5169.

Taton, A.; Grubisic, S.; ERTZ, D.; Hodgson, D.A.; PicCARdI, R.; Biondi, N.; Tredici, M.R.; Mainini, M.; Losi, D.; Marinelli, F. \& Willmotte, A. (2006): Polyphasic study of Antarctic cyanobacterial strains. - Journal of Phycology 42: 1257-1270.

Trifinopoulos, J.; Nguyen, L.T.; von Haeseler, A. \& Minh, B.Q. (2016): W-IQ-TREE: a fast online phylogenetic tool for maximum likelihood analysis. - Nucleic Acids Research 44: W232-W235.

Turicchia, S.; Ventura, S.; KomÁrkoví, J. \& KomÁReK, J. (2009): Taxonomic evaluation of cyanobacterial microflora from alkaline marshes of northern Belize. 2. Diversity of oscillatorialean genera. - Nova Hedwigia 89: $165-200$.

Supplementary material

The following supplementary material is available for this article:

Table S1. Comparison of the 16S rRNA gene sequence

similarity among Desikacharya and Minunostoc.

This material is available as part of the online article (http:// fottea.czechphycology.cz/contents)

(C) Czech Phycological Society (2021)

Received March 2, 2021

Accepted May 11, 2021 